\title{
Crystals and Mud in Property Law
}

\author{
Carol M. Rose*
}

Property law, and especially the common law of property, has always been heavily laden with hard-edged doctrines that tell everyone exactly where they stand. Default on paying your loan installments? Too bad, you lose the thing you bought and your past payments as well. Forget to record your deed? Sorry, the next buyer can purchase free of your claim, and you are out on the street. Sell that house with the leak in the basement? Lucky you, you can unload the place without having to tell the buyer about such things at all.

In a sense, hard-edged rules like these-rules that I call "crystals"are what property is all about. If, as Jeremy Bentham said long ago, property is "nothing but a basis of expectation," 1 then crystal rules are the very stuff of property: their great advantage, or so it is commonly thought, is that they signal to all of us, in a clear and distinct language, precisely what our obligations are and how we may take care of our interests. ${ }^{2}$ Thus, I should inspect the property, record my deed, and make my payments if I don't want to lose my home to unexpected physical, legal, or financial impairments. I know where I stand and so does everyone else, and we can all strike bargains with each other if we want to stand somewhere else.

Economic thinkers have been telling us for at least two centuries that the more important a given kind of thing becomes for us, the more likely we are to have these hard-edged rules to manage it. ${ }^{3}$ We draw

* This article was originally prepared as a paper for the Conference on Property and Rhetoric, sponsored in June 1986 by Northwestern University and funded by the American Bar Foundation. The Siragusa Foundation provided additional research support. As the paper evolved, I received many helpful comments from patient audiences, initially at that wonderful institution, the Yale Law School Half-Baked Lunch, and later at faculty seminars at the Northwestern University Law School, New York University Law School, and Tulane Law School. I particularly thank Allan Axelrod, Randy Barnett, Victor Goldberg, Ian Macneil, Thomas Merrill, Geoffry Miller, Stewart Sterk, Cass Sunstein, John Stick, and David Van Zandt for their critiques and insights. All errors, of course, are my own.

1. J. Bentham, Theory of Legrslation, Principles of the Civil Code pt. 1, ch. 8 , at 68 (Baxi ed., Hildreth trans., 1975).

2. See, e.g., Holderness, A Legal Foundation for Exchange, 14 J. LEgal Stud. 321, 322-26 (1985) (favors property doctrines that have narrow, specific definition of entitlements-holders, because they lower information costs and transaction costs).

3. 2 W. BLACKStONe, CommentaRies ON THE LAwS OF ENGLAND 4 (1766 \& photo. reprint 1979) (necessary to create individual property in things as these things became "conveniences" in increasing "refine[ment]" of human life); id. at 7 (property in land occurred with development of agriculture); see also Demsetz, Toward a Theory of Properly Rights, 79 Am. Econ. REv. PROC. 347 (1967) (property rights develop with increase in value of resources); R. Pos- 
these ever-sharper lines around our entitlements so that we know who has what, and so that we can trade instead of getting into the confusions and disputes that would only escalate as the goods in question became scarcer and more highly valued. ${ }^{4}$

At the root of these economic analyses lies the perception that it costs something to establish clear entitlements to things, and we won't bother to undertake the task of removing goods from an ownerless "commons" unless it is worth it to us to do so. ${ }^{5}$ What makes it worth it? Increasing scarcity of the resource, and the attendant conflicts over it. To use the example given by Harold Demsetz, one of the most notable of the modern economists telling this story, when the European demand for fur hats increased demand for (and scarcity of) fur-bearing animals among Indian hunters, the Indians developed a system of property entitlements to the animal habitat. ${ }^{6}$ Economic historians of the American West tell a similar story about the development of property rights in various minerals and natural resources. Easy-going, anything-goes patterns of appropriation at the outset came under pressure as competition for resources increased, and were finally superseded by much more sharply defined systems of entitlement. ${ }^{7}$ In effect, as our competition for a resource raises the costs of conflict about it, those conflict costs begin to outweigh the costs of taking it out of the commons and establishing clear property entitlements. We establish a system of clear entitlements so that we can barter and trade for what we want instead of fighting.

The trouble with this "scarcity story" is that things don't seem to work this way, or at least not all the time. Sometimes we seem to substitute fuzzy, ambiguous rules of decision for what seem to be perfectly clear, open and shut, demarcations of entitlements. I call this occurrence the substitution of "mud" rules for "crystal" ones.

Thus, in the examples with which I began, we find that, over time, the straightforward common law crystalline rules have been muddied repeatedly by exceptions and equitable second-guessing, to the point

NER, ECONOMIC ANALYSIS OF LAw 30 (3d ed. 1986) (value of fixed entitlements has been known "for hundreds of years").

4. Holderness, supra note 2 , at $322-24$ (specified entitlements necessary for trade); $W$. Blackstone, supra note 3 , at 4 (property rights necessary to avoid "innumerable tumults" of many persons striving for same thing); see also Demsetz, Professor Michelman's Unnecessary and Futile Search for the Philosopher's Touchstone, 24 Nomos: ETHICs, Economics, AND THE LAw 41, 46 (1982) (major function of property and exchange system is to attenuate group conflict).

5. See, e.g., Cheung, The Structure of a Contract and the Theory of a Non-Exclusive Resource, 13 J.L. \& ECON. 49, 64 (1970) (notes increasing policing costs as property rights become increasingly specific); see also Hardin, The Tragedy of the Commons, 162 Science 1243 (1968).

6. Demsetz, supra note 3, at 347-49.

7. See Anderson \& Hill, The Evolution of Property Rights: A Study of the American IVest, $18 \mathrm{~J} . \mathrm{L}$. \& ECoN. 163, 165, 168-79 (1975) (increasingly sharp definitions of property in land, livestock, water); Umbeck, $A$ Theory of Contract Choice and the Califormia Gold Rush, 20 J.L. \& Econ. 421, 432-37 (1977) (same in gold mining); see also J. HURST, LAw AND Economic GrowTH 298 (1964) (legal recognition of property in standing timber essential to early Wisconsin logging industry). 
that the various claimants under real estate contracts, mortgages, or recorded deeds don't know quite what their rights and obligations really are. ${ }^{8}$ And the same pattern has occurred in other areas too. In Wisconsin's Prah $v$. Maretti, ${ }^{9}$ for example, what seemed to be a workable crystalline rule about sunlight rights-that your neighbor has no right to the sunlight that crosses your lot unless your neighbor has gotten an easement from you ${ }^{10}$ - has been transformed into a mud doctrine. Now, if you block the light, your neighbor may have a nuisance action against you-at least in Wisconsin. ${ }^{11}$

Now, nuisance is one of those extraordinarily shapeless doctrinal areas in the law of property. In Prah, the nuisance question hinged on a typically vague formulation: "all the underlying facts and circumstances." 12 Does it matter that you built first? ${ }^{13}$ Could you or your neighbor have adjusted your respective buildings to avoid the problem? ${ }^{14}$ How valuable was the sunlight to you, and how valuable to your neighbor? ${ }^{15}$ You don't know in advance how to answer these questions and how to weigh the answers against each other; that is to say, you don't know whether your building will be found a nuisance or not, and you won't really know until you go through the pain and trouble of getting a court to decide the issue after you have built it or have had plans drawn up.

Quite aside from the wealth transfer that may accompany a change in the rules, then, the change may sharply alter the clarity of the relationship between the parties. But a move to the uncertainty of mud seems disruptive to the very practice of a private property/contractual exchange society. Thus, it is hardly surprising that we individually and collectively attempt to clear up the mud with new crystal rules-as

\section{See Part I infra.}

9. 108 Wis. 2d 223, 321 N.W.2d 182 (1982).

10. For this position, see Parker v. Foote, 19 Wend. 308 (N.Y. Sup. C.t 1838); Fontainebleau Hotel Corp. v. Forty-Five Twenty-Five, Inc., 114 So. $2 d 357$ (Fla. Dist. Ct. App. 1959), cert. denied, 117 So. 2d 842 (Fla. 1960). Both cases rejected a British doctrine of "ancient lights" whereby a right to sunlight could be acquired by prescription.

11. No jurisdictions have followed Wisconsin's nuisance doctrine in sunlight, and at least one state has explicitly rejected it. See Sher v. Leiderman, 181 Cal. App. 3d 867, 226 Cal. Rptr. 698 (1986) (rejecting Prah in favor of older no-duty rule). However, several states in the last few years, notably New Mexico, have passed statutes to protect builders of solar energy collection devices, and in the process they have muddied the older allocation of property rights in sunlight. The New Mexico strategy effectively severs sunlight from land ownership and guarantees the right of the first "appropriator" of the sunlight. The result is that sunlight, instead of being the object of an orderly trade in easements, is now given to the winner of the race to develop. It is not altogether clear, however, what counts as a qualified "appropriation"-the sunlight must be put to a somewhat nebulously defined "beneficial use." Moreover, sales between first appropriators and later purchasers are subject to yet another set of qualifying criteria. For a description of the New Mexico legislation, as well as other state sunlight protection statutes, see Eisenstadt, Access to Solar Energy: The Problem and its Current Staltus, 22 Nat. ResourCes J. 21, 33-39 (1982).

12. Prah, 108 Wis. 2d at 242; 321 N.W. 2 d at 192.

13. Id. (cost of avoiding harm a factor).

14. Id. (extent of harm and availability of alternative remedies a factor).

15. Id. (suitability of solar heat a factor). 
when private parties contract out of ambiguous warranties, ${ }^{16}$ or when legislatures pass new versions of crystalline record systems ${ }^{17}$-only to be overruled later, when courts once again reinstate mud in a different form.

These odd permutations on the scarcity story must give us pause. Why should we shift back and forth instead of opting for crystal when we have greater scarcity? Is there some advantage to mud rules that the courts are paying attention to? And if so, why do we not opt for mud rules instead?

This paper is about the blurring of clear and distinct property rules with the muddy doctrines of "maybe or maybe not," and about the reverse tendency to try to clear up the blur with new crystalline rules. Part I illustrates the back-and-forth pattern between crystals and mud by briefly describing what has happened to the supposedly crystalline character of the three examples with which I began. Part II then examines some theoretical positions that have attempted to explain part or all of this circular pattern. Building on that discussion, Parts III and IV focus more closely on the element of hardship or "forfeiture" that so frequently seems to put pressure on crystalline rules. Finally, in Part V, the paper suggests that the cleft between crystal and mud may not, under ordinary circumstances, really be so deep as our rhetoric suggests, and concludes that it is precisely as rhetoric that the cleft between crystal and mud matters most to us.

\section{From Crystal to Mud and Back: Three Examples}

From all appearances, and despite the obvious advantages of crystalline property rules for the smooth flow of trade and commerce, we seem to be caught in an era of intractable and perhaps even increasing muddiness. ${ }^{18}$ One could choose any number of areas to see this, and I will briefly discuss only a few, namely the examples with which I began. The first is the example of the law of caveat emptor in real estate transactions, which in recent years has shown a strikingly generalized pattern of the slide towards mud.

\section{A. The Demise of Caveat Emptor}

For several hundred years, and right up to the last few decades, caveat emptor was the staple fare of the law of real estate purchases, at least for buildings already constructed. ${ }^{19}$ The purchaser was deemed

16. See, e.g., text accompanying note 31 infra (concerning waivers of warranties).

17. See, e.g., text accompanying notes 68-69 infra (concerning Torrens statutes).

18. Cf. Cribbet, Concepts in Transition: The Search for a New Definition of Property, 1986 U. ILL. L. REv. 1 (sees shift in variety of areas-zoning, landlord-tenant, eminent domain, warranties, and so on-away from firm doctrines to greater recognition of exceptions, special cases, and larger claims; but characterizes shift as recognition of "social side" of property).

19. See, e.g., Swinton v. Whitinsville Sav. Bank, 311 Mass. 677, 42 N.E.2d 808 (1942); Levy v. C. Young Constr. Co., 46 N.J. Super. 293, 134 A.2d 717 (N.J. Super. Ct. App. Div. 
perfectly capable of inspecting the property and deciding for himself whether he wanted it, and if anyone were foolish enough to buy a pig in a poke, he deserved what he got. Short of outright fraud that would mislead the buyer, the seller had no duties to disclose anything at all. ${ }^{20}$

One chink in this otherwise smooth wall was the doctrine of "latent defects," which, like the exception for fraud, suggested that perhaps the buyer really can't figure things out entirely. For some time now, in at least some states, a seller has had to tell a buyer about material problems with the property known to the seller but undiscoverable by the purchaser upon reasonable inspection. ${ }^{21}$ The doctrine began to raise a few problems of muddiness: What defects are "material"? What does the seller "know"? To what extent should the buyer "reasonably" have to inspect for herself? ${ }^{22}$

Within the last few decades, the movement to mud in this area has become even more pronounced as some courts and legal commentators maintain that builder/vendors implicitly warrant a new house "habitable."23 But what does habitability mean? Is the house's habitability coterminous with the local housing code, or does "habitability" connote some less definite standard? ${ }^{24}$ What if the defects were obvious, and just what does "obvious" mean, anyway?25 We don't know until we litigate the issues.

1957), aff'd, 26 N.J. 330,139 A.2d 738 (1958) (overruled in McDonald v. Mianecki, 159 N.J. Super. 1, 386 A.2d 1325 (1978), aff'd, 79 N.J. 275, 398 A.2d 1283 (1979)); Tudor v. Heugel, 132 Ind. App. 579, 178 N.E.2d 442 (1961) (overruled in Their v. Heuer, 264 Ind. 1, 280 N.E.2d 300 (1972); Grand, Implied and Statutory Warranties in the Sale of Real Estate: The Demise of Caveat Emptor, 15 REAL EsT. L.J. 44, 44-45 (1986); see also Hamilton, The Ancient Maxim Caveat Emptor, 40 Yale L.J. 1133, 1 179-82 (1931) (caveat emptor prevailed in 19th century American commercial law).

20. The exception-a warranty of workmanship for uncompleted buildings-presumably existed because the purchaser had no opportunity to inspect in advance. See Roberts, The Case of the Unwary Home Buyer: The Housing Merchant Did It, 52 Connell L.Q. 835, 838 (1967); Bearman, Caveat Emptor in Sales of Realty - Recent Assaults Upon the Rule, 14 VAND. L. REv. 541, 543-44 (1961) (traces the exception to a British case, Miller v. Cannon Hill Estates, Ltd., 2 K.B. 113 (1931)).

21. See Haskell, The Case for an Implied Warranty of Quality in Sales of Real Property, 53 Geo. L.J. $633,642-43$ (1965). In California, this doctrine took special force with cases involving land fill. See Clauser v. Taylor, 44 Cal. App. 2d 453, 112 P.2d 661 (1941); Rothstein v. Janss Inv. Corp., 45 Cal. App. 2d 64, 68, 113 P.2d 465, 467 (1941). But now the doctrine extends to "material" defects of all kinds. See, e.g., Lingsch v. Savage, 213 Cal. App. 2d 729, 29 Cal. Rptr. 201 (1963).

22. See, e.g., Lingsch v. Savage, 213 Cal. App. 2d 735, 29 Cal. Rptr. 209 (discusses what is within buyer's "reach").

23. See, e.g., Theis v. Heuer, 264 Ind. 1, 280 N.E.2d 300 (1972); McDonald v. Mianecki, $79 \mathrm{~N} . J .275,398$ A.2d 1283 (1979) (and authorities cited therein, 79 N.J. at 285-88, 398 A.2d at 1288-89).

24. See Oates v. JAG, Inc., 314 N.C. 276, 279-80, 333 S.E.2d 222, 225 (1985) (some code violations alleged, quaere whether this allegation necessary to find house uninhabitable, or whether each and every code defect makes a house uninhabitable). For a similar problem in the relatively recent doctrine whereby a landlord warrants the habitability of residential leases, see Javins v. First Nat'l Realty Corp., 428 F.2d 1071, 1082 nn. 62-63 (D.C. Cir.), cert. dented, 400 U.S. 925 (1970). Cf. Bearman, supra note 20, at 575 (would require that new houses meet standards of profession, acknowledging that this standard requires judicial discretion).

25. Oates v. JAG, Inc. 314 N.C. 276, 281, 333 S.E.2d 226 (issue whether defects were 
Even if builder/vendors' warranties do muddy up property rights, there are some plausible reasons for them. After all, the builder/vendors are professionals, and they should know more about their own construction; they even might have avoided the problems in the first place by building more carefully. ${ }^{26}$ It is somewhat more difficult to extend those arguments to sellers who are themselves merely homeowners instead of builder/vendors, yet we find that even these nonprofessional sellers have increasing obligations to anticipate the buyers' desires, and to inform buyers about disagreeable factors that might make the buyers think twice. ${ }^{27}$ A California court, for example, has ruled that the sellers had to inform the buyer that a mass murder had taken place a decade previously in a particular house. ${ }^{28}$ The courts now seem to presume a buyer who can't figure out much at all, and to protect that buyer they have adopted a mud standard: like good neighbors, sellers must tell buyers about any "material" defects-whatever those may be. ${ }^{29}$

The increasingly mushy relationship between buyers and sellers of real estate has parallels in the law of consumer sales generally, and the real estate cases borrow much of their language from other cases about such items as cars, hairdryers, and water heaters. ${ }^{30}$ These developments might suggest that the scarcity story is exactly backwards, and that the normal movement of property law is not towards ever harderedged rules, but towards the fluidity and imprecision of mud.

But there is a countermove as well: Even if the legal rules have moved toward mud, private bargainers often try to install their own little crystalline systems through contractual waivers of warranties or disclosure duties (for example, the "as is" or "no warranty" sale). These private efforts in effect move things into the pattern of a circle, from crystal to mud and back to crystal. And the circle turns once again when the courts ban such waivers, as they sometimes do, ${ }^{31}$ and firmly

obvious); see also Haskell, supra note 21, at 648 (proposes test of several factors to be decided on a case by case basis, including "knowability" of defect to buyer).

26. See, e.g., Humber v. Morton, 426 S.W.2d 554, 562 (Tex. 1968) (criticizes caveat emptor rule as "lending encouragement to the unscrupulous, fy-by-night operator and purveyor of shoddy work"). If the cost to the builder of "warranty" work is higher than expected damages, however, builders may not build better but may rather accept losses from occasional damage suits.

27. Cf. McDonald v. Mianecki, 79 N.J. 275, 288, 398 A.2d 1283, 1289 (1979) (house purchaser often relies on expertise of builder).

28. Reed v. King, 145 Cal. App. 3d 261, 193 Cal. Rptr. 130 (1983).

29. See Lingsch v. Savage, 213 Cal. App. 2d 729, 740-41, 29 Cal Rptr. 201, 209 (1963) (requirement of disclosure of material defects unknown to buyer, even with "as is" provision in contract, "equates sound law with good morals").

30. See, e.g., McDonald v. Mianecki, 79 N.J. 275, 291-92, 398 A.2d 1283, 1291 (1979) (using for support a case on defect in hot water heater); Wawak v. Stewart, 247 Ark. 1093, 1095,449 S.W.2d 922, 923 (1970) (comparing new house warranty to warranty on walking stick or kitchen mop). One obvious difference between a mop and a house, of course, is that the cost of an engineer's report on the mop is entirely disproportionate to the price paid for the thing itself-which is not so likely to be the case with respect to a house.

31. See Lingsch v. Savage, 213 Cal. App. 2d 729, 740-41, 29 Cal. Rptr. 201, 209 (1963) 
re-establish a rule of mud-only to be followed by even more artful waivers.

The back-and-forth pattern of crystal and mud is even more evident in the next example, the loan secured by landed property-a form of real estate transaction whose history has often been described as resembling a seesaw. ${ }^{32}$

\section{B. Of Mortgages and Mud}

Early common law mortgages were very crystalline indeed. They had the look of pawnshop transactions and were at least sometimes structured as conveyances: I borrow money from you, and at the same time I convey my land to you as security for my loan. ${ }^{33}$ If all goes well, I pay back my debt on the agreed "law day," and you reconvey my land back to me. But if all does not go well and I cannot pay on the appointed day, then, no matter how heartrending my excuse, I lose my land to you and, presumably, any of the previous payments I might have made. ${ }^{34}$ As the fifteenth century commentator Littleton airily explained, the name "mortgage" derived from the rule that, if the debtor "doth not pay, then the land which he puts in pledge ... is gone from him for ever, and so dead."35

This system had the advantage of great clarity, but it sometimes must have seemed very hard on mortgage debtors to the advantage of scoundrelly creditors. Littleton's advice about the importance of specifying the precise place and time for repayment, for example, conjures up images of a wily creditor hiding in the woods on the repayment day to frustrate repayment; presumably, the unfound creditor could keep the property. ${ }^{36}$ But by the seventeenth century, the intervention of

("as is" clause does not necessarily immunize seller from disclosure obligations); see also Grand, supra note 19, at $51-52$ (courts second-guess warranty disclaimers; normally require them to be noticeable).

32. See, e.g., Wechsler, Through the Looking Glass: Foreclosure by Sale as De Facto Strict Foreclosure-An Emptrical Study of Mortgage Foreclosure and Subsequent Resale, 70 CoRnezL L. REv. 850, 855 n.25 (1985) (quoting Madwoy, A Mortgage Foreclosure Primer, 8 Clearinghouse Rev. 146, $148(1974))$.

33. See The Treatise on the Laws and Customs of the Realm of England Commonly Called Glanvill 121 (G.D.G. Hall trans. and ed. 1965) (borrower may immediately give seisin to the creditor). This treatise dates from the twelfth century. Id. at xi. In the fifteenth century treatise, LrrTLETON's TENURES $\$ 377$ (E. Wambaugh ed. 1903), the mortgage is described as a conditional feoffment. For details of Littleton's life, see id. at xiii-lix. See also 3 Powell on Real Property 438 (P. Rohan ed. 1985) [hereinafter Powell].

34. 3 Powel, supra note $33, \uparrow 438$ (slightest deviation from conditions resulted in loss); Wechsler, supra note 32, at 856 (uses term "law day") (citing G. OSBORNE, G. NELson \& D. WhrtMan, Real Estate Finance Law $\$ 1.2$, at 7 (1979).

35. LitTLETON's TenUREs, supra note 33 , at $\$ 332$.

36. Id. at $\$ 340$ (remarking that though some thought the appropriate place was the property itself, the debtor had to go find the creditor, "if he be then in ... England ....") A few pages later, in a perfect example of the crystal style, he suggests elaborate ex ante specifications of the place for repayment. Id. at $\$ 342$; see also Wechsler, supra note 32 , at 856 (noting the harshness of this early rule). 
courts of equity had changed things. ${ }^{37}$ By the eighteenth and nineteenth centuries, the equity courts were regularly giving debtors as many as three or four "enlargements" of the time in which they might pay and redeem the property before the final "foreclosure," even when the excuse was lame. ${ }^{38}$ One judge explained that an equity court might well grant more time even after the "final" order of "foreclosure absolute," depending on the particular circumstances. ${ }^{39}$

The muddiness of this emerging judicial remedy argued against its attractiveness. Chief Justice Hale complained in 1672 that, "[b]y the growth of Equity on Equity, the Heart of the Common Law is eaten out, and legal Settlements are destroyed; . . . as far as the Line is given, Man will go; and if an hundred Years are given, Man will go so far, and we know not whither we shall go."40 Instead of a precise and clear allocation of entitlements between the parties, the "equity of redemption" and its unpredictable foreclosure opened up vexing questions and uncertainties: How much time should the debtor have for repayment before the equitable arguments shifted to favor the creditor? ${ }^{4}$ What sort of excuses did the debtor need ${ }^{42}$ Did it matter that the property, instead of dropping in the lap of the creditor, was sold at a foreclosure sale?43

But as the courts moved towards muddiness, private parties attempted to bargain their way out of these costly uncertainties and to reinstate a crystalline pattern whereby lenders could get the property immediately upon default without the costs of foreclosure. How about a separate deal with the borrower, for example, whereby he agrees to convey any equitable interest to the lender in case of default? ${ }^{44}$ Nothing doing, said the courts, including the United States Supreme Court, which in 1878 stated flatly that a mortgagor could not initially bargain

37. See How v. Vigures, 21 Eng. Rep. 499 (1628-29) (creditor asks equity court for property when debt not paid).

38. See, e.g., Anonymus [sic] Case, 27 Eng. Rep. 621 (1740) (debtor given additional 6month extension after three previous extensions, on the third of which he had promised to ask for no more extensions); Nanny v. Edwards, $38 \mathrm{Eng}$. Rep. 752 (1827) (three extensions claimed usual; enlargement requires some excuse though "not . . . a very strong one"); Holford v. Yate, 69 Eng. Rep. 631, 633 (1855) (grants extension though debtor's excuse called "very weak").

39. Campbell v. Holyland, 7 Ch. D. 166, 172 (1876); see also Tefft, The Myth of Strict Foreclosure, 4 U. CHI. L. REv. 575, 578 (1937) (describing various redemption opportunities available to mortgagor).

40. Roscarrick v. Barton, 22 Eng. Rep. 769, 770 (1672).

41. Novosielski v. Wakefield, 34 Eng. Rep. 161, 162 (1811) (expressing regret at extension because of hardship on creditor).

42. See, e.g., Holford v. Yate, 69 Eng. Rep. 631, 632 (1855) (argument about sufficiency of debtor's excuse); Campbell v. Holyland, 7 Ch. D. 166, 173 (1876) (discussing some considerations counting as excuses).

43. Perine v. Dunn, Johnson's Ch. Rep. 140, 141 (N.Y. 1819) (enlargement only on strict foreclosure, since in the case of a sale, debtor gets surplus).

44. For a discussion of the permutations, see Comment, Mortgages-Deed in Lieu of Foreclosure-Validity, 36 MicH. L. REv. 111 (1937). 
away his "equity of redemption." 45 Well, then, how about an arrangement whereby it looks as if the lender already owns the land, and the "borrower" only gets title if he lives up to his agreement to pay for it by a certain time? This seemed more promising: In the 1890s California courts thought it perfectly correct to hold the buyer to his word in such an arrangement, and to give him neither an extension nor a refund of past payments. ${ }^{46}$ By the 1960 s, however, they were changing their minds about these "installment land contracts." 47 After all, these deals really had exactly the same effect as the old-style mortgages-the defaulting buyer could lose everything if he missed a payment, even the very last payment. Human vice and error seemed to put the crystal rule in jeopardy: In a series of cases culminating with a default by a "willful but repentant" little old lady who had stopped paying when she mistakenly thought that she was being cheated, the California Supreme Court decided to treat these land contracts as mortgages in disguise. ${ }^{48}$ It gave the borrower "relief from forfeiture" 49 - a time to reinstate the installment contract or get back her past payments. ${ }^{50}$

With mortgages first and mortgage substitutes later, we see a backand-forth pattern: crisp definition of entitlements, made fuzzy by accretions of judicial decisions, crisped up again by the parties' contractual arrangements, and once again made fuzzy by the courts. Here we see private parties apparently following the "scarcity story" in their private law arrangements: when things matter, the parties define their respective entitlements with ever sharper precision. Yet the courts seem at times unwilling to follow this story or to permit these crystalline definitions, most particularly when the rules hurt one party very badly. The cycle thus alternates between crystal and mud.

But the subject matter that has truly defied the scarcity story, often to the despair of property professors, has not been mortgages or mortgage substitutes. It has been the recording system, to which I now turn.

\section{Broken Records}

In establishing recording systems, legislatures have lent support to private parties' efforts to sharpen the definition of their entitlements.

45. Peugh v. Davis, 96 U.S. 332, 337 (1878).

46. Glock v. Howard and Wilson Colony Co., 123 Cal. 1 (1898).

47. See Hetland, The California Land Contract, 48 CaLIF. L. Rev. 729 (1960).

48. MacFadden v. Walker, 5 Cal. 3d 809, 488 P.2d 1353, 97 Cal. Rptr. 537 (1971); Note, V'endor and Vendee-Specific Performance, 5 LoY. L.A.L. REv. 435 (1972) (reviewing earlier cases).

49. MacFadden v. Walker, 5 Cal. 3d 809, 488 P.2d 1353, 97 Cal. Rptr. 537, 539 (1971); see also Barkis v. Scott, 34 Cal. 2d 116, 208 P.2d 367 (1949) (relief to defaulting vendee granted); Freedman v. The Rector, 37 Cal. 2d 16, 230 P.2d 629 (1951) (basis for relief from forfeiture established).

50. For related developments in other jurisdictions, see Annotation, Specific Performance of Land Contract Notwithslanding Failure of Vendee to Make Required Payments on Time, 55 A.L.R.3d 10 (1974). 
The raison d'etre of such systems is to clarify and perfectly specify landed property rights for the sake of easy and smooth transfers of land.

But the Anglo-American recording system in fact has been a saga of frustrated efforts to make clear who has what in land transfers. Common law transfers of land required a certain set of formalities between the parties, but thereafter, conflicting claims were settled by the age-old principle, "first in time, first in right."51 Thus, on Tuesday I might sell my farm to you, and on Wednesday I might wrongfully purport to sell it once again to innocent Farmer Brown. Poor Farmer Brown remains landless even though he knew nothing about the prior sale to you and indeed had no way of knowing about it. ${ }^{52}$ This outcome was hardly satisfactory from a property rights perspective. "First in time, first in right" may work well enough in a community where everyone knows all about everyone else's transactions, but outside that context, the doctrine does little to put people on notice of who owns what, and the opportunities for conflicting claims are endless.

But the efforts to remedy this flaw have gone through new cycles of certainty and uncertainty. Henry VIII attempted-without great success-to establish public registration of land claims through the Statute of Enrollments in 1536. ${ }^{53}$ Versions of the Statute resurfaced in Massachusetts' 1640 recording act and in other seventeenth and eighteenth century colonial recording acts, all of which were much more widely (though still somewhat irregularly) applied than their Henrician model had been. 54

Henry's Statute and its original American counterparts reflected an emphatically crystalline view of property. Their literal language suggests that they were versions of what has come to be called a "race" statute: the first purchaser to record (the winner of the "race" to the registry) can hold his title against all other claimants, whether or not he was in fact the first to purchase. ${ }^{55}$ In such a system, the official records become an unimpeachable source of information about the status of land ownership; the law counts the record owner, and only the record owner, as the true owner. The purchaser can buy in reliance on the

51. 6A Powell ๆ 880 (formalities); If 904 (first in right principle).

52. He might, however, have an action against the seller for breach of a warranty of "seisin," i.e., a covenant that I really own what I purport to sell. See 6A PoweLL I 896.

53. Patton, Evolution of Legislation on Proof of Title to Land, 30 WASH. L. REv. 224, 225-26 (1955) (widespread evasion of Statute of Enrollments); 6A PowelL If 880 (Statute of Enrollments circumvented by development of the lease).

54. See Philbrick, Limits of Record Search and Therefore of Notice, 93 U. PA. L. Rev. 125, 140; 6A Powell I 904[1]; R. Powell \& P. Rohan, On Real Property ๆ 912, at 1046-47 (1968). But see Konig, Community Custom and the Common Law: Social Change and the Development of Land Law in Seventeenth-Century Massachusetls, 18 Am. J. Legal. Hist. 137, 143-44 (seventeenth century laxity about deed recordation in Massachusetts).

55. Patton, supra note 53, at 226 (Enrollments and original colonial statutes of the "race" type); Philbrick, supra note 54, at 139-40 (original intent of recording statutes was to require recordation for valid title, though that intent was undermined by courts); see also $6 \mathrm{~A}$ POWELL I 905[1][a]. 
records without fear of divestment by some unknown interloper, and without the need to make some cumbersome extra-record search for such potential interlopers.

This system was too crystalline to last. The characters to muck up this crystalline system by now should be sounding familiar: ninnies, hard-luck cases, and the occasional scoundrels who take advantage of them. What are we to do, for example, with the silly fellow who buys an interest in property but simply forgets to record? Or with the more conscientious one who does attempt to record his interest, but whose records wind up in the wrong book? ${ }^{56}$ Or with the lost soul whose impeccably correct filing is dropped behind the radiator by the neglectful clerk?57 Some courts take a hard line, perhaps concluding that the first owner was in a better position than our innocent outsider-that is, the next purchaser-to detect and correct the flaws in the records. ${ }^{58} \mathrm{But}$ our sympathies for the luckless unrecorded owner put pressure on the recording system that would divest him in favor of the later-arriving outsider. 59

Our sympathies are all the greater when the outsider is not so innocent after all. What shall we do, say, when the unrecorded first buyer is snookered out of his claim by a later purchaser who knows perfectly well that the land had already been sold? Shall we allow this nasty second buyer to perfect a claim simply because he carefully follows the official recording rules? ${ }^{60}$ This thought was too much for the courts of equity, and too much for American legislatures as well. By the early nineteenth century, the British equity courts had imported an element of non-record "notice" into what had initially been a "race" system. Under these doctrines, the later purchaser could take free of the prior claims only if he did not know about those prior claims, either from the records or from non-record facts that should put him "on notice."61

56. See, e.g., Farabee v. McKerrihan, 172 Pa. 234, 33 A. 583 (1896) (instrument copied into wrong book held valid).

57. Bamberg v. Harrison, 89 S.C. 454,71 S.E. 1086 (1911) (instrument misplaced, held invalid against subsequent purchaser; the case involved an interest in a horse).

58. See Bamberg v. Harrison, 89 S.C. 454, 71 S.E. 1086 (1911); In re 250 Bell Road, Etc., 479 Pa. 222, 388 A.2d 297, 300 n.3 (1978) (person offering document has duty to see that it is properly recorded and cannot hide behind recorder's error).

59. See Farabee v. McKerrihan, 172 Pa. 234, 33 A. 583, 583 (1896) (if holder of interest has done all he can, it would be a "hard rule that would deprive him" of interest (citing Glading v. Frick, $88 \mathrm{~Pa} .460,464$ (1879))).

60. See W. HuRST, supra note 7, at 304-05 (some later 19th century Wisconsin timberland "land cruisers" searched records for unrecorded claims, purchased same from record owners at nominal prices; Wisconsin courts held that prior unrecorded deeds prevailed over noninnocent record purchaser); see also Grayson v. Buffington, $233 \mathrm{Md}$. 340, 196 A.2d 893 (1964) (actual knowledge of prior deed renders buyer not "bona fide"); $c f$. Industrial Outdoor Displays v. Reuter, 162 So.2d 160, 162 (La. Ct. App. 1964) (purchasers not bound by unrecorded claims even if they have actual notice of them).

61. See, e.g., Doe d. Robinson v. Allsop, 106 Eng. Rep. 1145, 1147 (1821). This case was at law and did not itself grant relief to the nonrecording earlier interest-holder, though it noted the availability of equitable relief. Of course, many British land claims were not recorded at all. See text accompanying note $\mathbf{5 3}$ supra. 
American legislatures followed this move to such a degree that, at present, only a handful of states maintain a race system with any rigor. The other states deny the subsequent claim of the person who had or should have had notice of the earlier claim. ${ }^{62}$

This development means mud: What "should" a purchaser know about, anyway? To be sure, if someone is living on the land, perhaps the potential purchaser should make a few inquiries about the occupant's status. But what if the "occupant's" acts are more ambiguous, consisting of, say, shovelling some manure onto the contested land? Well, said one court, a buyer should have asked about the source of all that manure - and since he didn't, and thus did not find out about the manure shoveller's prior but unrecorded claim, the later buyer did not count as an innocent; his title was a nullity. ${ }^{63}$

With the emergence of this judicial outlook, the crystalline idea of the recording system has come full cycle back to mud. ${ }^{64}$ To be sure, the recording system can give one a fair guess about the legal status of any given property. But by the end of the last century, as a Massachusetts court put it, "it would be seldom that a case could occur where some state of facts might not be imagined which, if it existed, would defeat a title." 65 Thus, the test of a title's "marketability" became a question of whether the title was subject to "reasonable" doubt-a matter, of course, for the discretion of the court. ${ }^{66}$ In the meantime, a whole title insurance industry sprang up to calm the fears of would-be purchasers who wanted to avoid questions about which doubts were reasonable and which were not. It is this industry, in a sense, that once again makes crystals out of the recording system's mud; and according to the reformers, it is this industry that now stands in the way of a more rational method of cleaning up the mess once and for all. ${ }^{67}$

Yet one must wonder whether cleaning up the mess might not just repeat the cycle of mud/crystal/mud. One of the most popular suggestions for reform is the so-called "Torrens" system, named for someone who thought that shipping registry methods could be used beneficially in real estate. In this system, all claims on a given property-sales, liens, easements, etc.-are first registered and then incorporated in a certificate. ${ }^{68}$ Torrens registration echoes eerily the colonial "race"

62. 6A Powell fi 905 [1][a]; 4 Amgrican Law of Property § 17.5, at 538-39 (A. Casner ed. 1952).

63. Miller v. Green, 264 Wis. 159, 58 N.W.2d 704 (1953).

64. See Philbrick, supra note 54, at 140 (judicial importation of "notice" into original recording statutes was "the notion by which the Massachusetts judges began the ruin of their own recording system, and that of this country generally"). There are also other problems with the recording system, particularly the multiplicity of records that must be searched. See Lobel, A Proposal for a Tille Registration System for Really, 11 U. RICH. L. Rev. 501, 505 (1977); Patton, supra note 53, at 227.

65. First African M. E. Church v. Brown, 147 Mass. 296, 298, 17 N.E. 549, 550 (1888).

66. Id.

67. Lobel, supra note 64, at 501-02, 514 .

68. For a brief history of Torrens registration, see Comment, Y'es I'irginia-There is a Tor- 
statutes: No unregistered claim counts, and the owner's certificate for a given property acts as the complete record of everything that anyone might claim.

Well, perhaps not everything. Government liens, fraudulent transactions, and, according to some courts, even simple errors or neglect in registration can produce unregistered claims that count. ${ }^{69}$ Hence this neo-race system provides no complete relief from the recording system's mud. Even after we look at the Torrens certificate, we still have to be on the lookout for the G-men, the forgers, and the ninnies who neglected to register their claims properly. Not a lot of mud, to be sure, but just wait. In some jurisdictions with a long history of Torrens registration, courts have in effect reestablished a "notice" system, defeating the interest of one who registers his claim when he knows about a prior unregistered one-or merely when he should have known about the prior claim. ${ }^{70}$ This practice, of course, means that the registry and certificate no longer count as the complete source of information about a property's title status.

The most striking aspect of these developments is that first the title recording acts, and later the registration systems, represented deliberate choices to establish crystalline rules for the sake of simplicity and ease of land sales and purchases. People who failed to use the records or registries were supposed to lose their claims, no matter how innocent they might have been, and no matter how nastily their opponents might have behaved. Yet these very crystalline systems have drifted back into mud through the importation of equitable ideas of notice-

rens $\mathrm{ACl}, 9$ U. RICH. L. REv. 301, 302-04 (1975). The Torrens system involves an initial judicial hearing to evaluate all claims to a given property. All claims found valid are registered, and thereafter all new claims are also registered and incorporated in the property's certificate. Id. at 303-04.

69. See, e.g., MAss. AnN. Laws ch. 185, $\$ 46$ (Law Co-op. 1987) (tenure of holder of certificate title); Baart v. Martin, 99 Minn. 197, 108 N.W. 945, 950 (1906) (equitable principles imply exception to statute while party to fraud still holds interest); Echols v. Olsen, 63 Ill.2d 270, 347 N.E.2d 720 (1976) (wife's equitable rights in property prevail over judgment creditor who did not rely on protection of Torrens registry); see also statutory exceptions for fraud, e.g., OHIo REv. CODE ANN. \& 5309.23 (Anderson 1981) (defrauded person may reopen registration within period of year, subject to rights of innocent third parties).

70. See Davies, Equity, Notice and Fraud in the Torrens System, 10 AlTa. L. Rev. 106, 110-11, 116 (1971). There is a somewhat comparable blurring in another recording reform effort, the marketable title statutes. These statutes attempt to abbreviate the title search by extinguishing unasserted claims that originate earlier than a certain number of years before a given transaction. See Barnett, Marketable Title Acts-Panacea or Pandemonium?, 53 CoRnel. L. Rev. 45,53 (1967). These statutes have a number of exceptions that reintroduce a need for a search going much further back and including matters outside any recorded instruments, e.g., for mining interests; restrictions that are "clearly observable"; or interests of a person in possession that would be "revealed by reasonable inspection." See Uniform Simplification of Land Transfers Act $\$ 3-306$ (1976). Some courts have also created exceptions requiring further record searches. See, e.g., F.A. Requarth Co. v. State, 38 Ohio St. 2d 77, 310 N.E.2d 581, 586 n.5 (1974) ("wild" deeds cannot constitute "root" of title); see also Barnett at $67-80,86,91$ (exceptions for forgeries, easements and covenants even if unrecorded, and other interests); Payne, In Search of Title, 14 ALA. L. Rev. 11, 293-326 (1961-62) (discussing remedies such as the Marketable Title Act). 
only to be replaced by new crystalline systems in the form of private contract or public legislation.

All these examples put the scarcity story to the test: What has happened to that story, according to which our rules should become more crystalline as resources become more scarce and more valuable? Why instead do we shift back and forth between hard-edged, yes-or-no crystalline rules and discretion-laden, post hoc muddy rules? Why do we have, over time, both mud and crystal rules with respect to the very same things, without any notable relation to their scarcity or plenty? The following section runs through a few theories that might help to explain this mystery.

\section{Some Tentative Explanations}

\section{A. Taking Sides}

One way to cope with the mud/crystal dilemma is to choose one type of rule over the other. Perhaps in keeping with the market-conscious spirit of the $80 \mathrm{~s}$, legal academics seem to favor crystals. In a recent article, Clifford Holderness argues that precise and complete specifications of entitlements are preferable to non-exclusive, tentative, open-ended entitlements. ${ }^{71}$ Why? Because precise entitlements facilitate the efficient allocation of goods; they allow us to identify rightholders and to organize trades with them until all goods arrive in the hands of those who value them most. Open-ended (or, as I would call them, muddy) entitlements generate two outcomes: Either they do not allow a complete identification of the parties with whom we need to trade, or they give some sort of entitlement to so many people that it becomes virtually impossible to cut a deal. ${ }^{72}$ In short, under muddy rules trading is so difficult that Pareto-superior moves remain unmade and goods languish in inefficient uses, even when someone would pay a great deal to use them more efficiently.

A similar argument appeared in an article that preceded Holderness' by a few years. Douglas Baird and Thomas Jackson also argue that crystalline specifications of rights are preferable to mud, because muddy doctrines unduly obfuscate commercial transactions. ${ }^{73}$ In discussing a filing system for commercial transactions (somewhat akin to a recording system for land), Baird and Jackson strongly urge that nonusers be penalized by losing their unfiled claims. If the filing system is easy to use, it is just too bad about the careless or foolish people who

71. Holderness, supra note 2 , at 322.

72. Id. at 324 .

73. Baird \& Jackson, Information, Uncertainty and the Transfer of Property, $13 \mathrm{~J}$. LEGAL STUD. $299,312-18$ (1984) (easier to live in a commercial world with a few simple rules; better to require use of commercial filing system than to allow system of actual notice). Crystal systems of course may cost something to establish. See, e.g., Anderson \& Hill, supra note 7, at 165-66 (property rights protection demands resources). Baird and Jackson's discussion presumes that a filing system for clarifying rights is already in place. 
fail to use it. ${ }^{74}$

Crystalline rules have a related advantage that has been much discussed of late: They discourage what is called "rent- seeking" behavior in decision-makers, particularly when those decision-makers are legislators. ${ }^{75}$ Take the situation of the legislature that has the authority to decide, say, the rate of taxation or the location of a new convention center. How will the decision be made, on the supposition that legislators are rational utility maximizers? The rent-seeking analysis suggests that the decision will be sold to the highest bidder, that is, to the interest group whose cohesiveness, tenacity, and resources allow it to bring the greatest temptations and the greatest pressure to bear on the legislators. ${ }^{76}$ And of course, the greater the authority of the decision-maker to change its mind-in other words, the muddier the rules, the greater the likelihood that interest groups will bid for whatever "asset" is the object of the decision-maker's discretionary choice, frittering away resources in the bidding process. ${ }^{77}$

The world of private transactions offers an analog to this fritteringaway scenario and indeed it is the very story that the economists tell about scarcity. In the absence of clear definitions around property rights, individuals dissipate resources in conflicts and bullying, or in taking precautions against being bullied. ${ }^{78}$ Crystalline rules, it seems, can halt this frittering away, be it public or private. Hard-edged rules define assets and their ownership in such a way that what is bought stays bought and can be safely traded to others, instead of repeatedly being put up for grabs.

Placing a kind of temporal overlay on these market-oriented preferences for crystal over mud, Frank Easterbrook recently applauded what he describes as the ex ante perspective of recent court decisions. Instead of trying to adjudge situations ex post, doing fairness to the parties from the perspective of what we know about their positions after things fall apart, the courts should try to consider matters from the perspective of persons similar to the parties at the outset of their relationship, and then figure out how we want them to think and act before all contingencies become realities. ${ }^{79}$ How do we want them to act? We want them to be careful planners so that things don't fall apart so easily.

74. Baird \& Jackson, supra note 73 , at 314 .

75. See, e.g., Buchanan, Rent Seeking and Profit Seeking, in J. Buchanan, R. Tollison, \& G. Tullock, Toward a Theory of the Rent SeEking Society 3, 8-1 1 (1980); see also R. Epstein, TAKINGS 203 (1985) (legislation may turn well-defined property rights into common pool, whose allocation is negative-sum game because of rent-seeking).

76. See M. Olson, The Rise and Decline of Nations 17-35 (1982).

77. See McChesney, Rent Extraction and Rent Creation in the Economic Theory of Regulation, J. LEGAL STUD. 101, 102-03 (1987) (political office carries asset of ability to impose costs on business, but impositions of those costs reduce investment, welfare).

78. See text accompanying notes 3-7, supra.

79. Easterbrook, The Supreme Court 1983 Term-Foreword: The Court and the Economic System, 98 HaRv. L. Rev. 4, 10-11, 19-21 (1984). 
To put it baldly, the ex ante perspective generally means sticking it to those who fail to protect themselves in advance against contingencies that, as it happens, work out badly for them. ${ }^{80}$ No muddiness here. All parties are presumed to be clear-sighted overseers of their own best interests; it is up to them to tie up all the loose ends that they can, and the courts should let the advantages and disadvantages fall where they may. Why? Because this will encourage people to plan and to act carefully, knowing that no judicial cavalry will ride to their rescue later. It will also allow the people that John Locke once called "the Industrious and Rational" to reap the fruits of their industry and rationality, and thus encourage productivity generally. ${ }^{81}$

But this approach means that the legal consequences of rules ought to be clear in advance, in other words, crystals rather than mud. The industrious and rational need to know that the consequences of their dealings are fixed, at least legally; no shifts of responsibility after the fact. Judicial punctiliousness about establishing and following clear rules, one would suppose, can influence behavior in the direction of greater productivity or carefulness.

Things would be easier if one could say that crystals are the uniform choice among the modern scholars knowledgeable about these matters. But that is not the case. Several scholars in recent years, particularly those associated with the Critical Legal Studies movement, have decried what we might call the excessively crystalline character of our legal system, which they associate with a kind of alienated individualism. ${ }^{82}$ Instead, they plump for more attention to mud, or, as the phrase has it, to "standards" instead of "rules." 83 Duncan Kennedy, who popularized the current distinction between rules and standards, argues that hard-edged, crystal doctrines systematically abandon people to the wiles of the bad and the mean-spirited. ${ }^{84}$ As Kennedy reminds us, Holmes even framed these doctrines in terms of the "bad man." They are designed to tell the bad man the limits within which he can get away with his badness. ${ }^{85}$ Standards, on the other hand, are aimed at protecting goodness and altruism ${ }^{86}$ - whatever internal contradictions may lurk in the notion of enforcing goodness by a legal order. ${ }^{87}$

If we are to be guided by standards rather than hard-edged rules,

80. Id. at 11-13 (fairness is ex post consideration, whereas ex ante judge will "pay less attention to today's unfortunates and more attention to the effects of the rules").

81. Id. at 10-11; J. Locke, Two TREATISES OF Government 333 (P. Laslett rev. ed. 1960) (3d ed 1968) (noting that God gave the world to the use of the industrious and rational and "not to the Fancy of Covetousness of the Quarellsom [sic] and Contentious").

82. See Kennedy, Form and Substance in Private Law Adjudication, 89 Harv. L. Rev. 1685, 1745,1774 (1976); see also Cribbet, supra note 18 (applauding abandonment of hard-edged property rules).

83. Kennedy, supra note 82 , at 1710 .

84. Id. at 1742 .

85. Id. at 1773 .

86. Id. at 1773-74.

87. Id. at 1722 . 
then our rules of decision must necessarily be muddy ones like "fairness" or "reasonableness," under which no one can entirely specify entitlements until faced with the consequences. ${ }^{88}$ As Frank Easterbrook quite bluntly states it, fairness is an ex post consideration; he apparently puts it second to the greater productivity he associates with the ex ante position. ${ }^{89}$ Lawrence Tribe has entangled himself in a debate with Easterbrook on this very point, ${ }^{90}$ rejecting Easterbrook's preference for the ex ante perspective, particularly in the context of constitutional decision-making. According to Tribe, when judges make decisions they not only try to facilitate the rational calculations of the actors and people similarly situated to the actors, they also tell a story about the kind of society we live in. Decisions, as he puts it, are constitutive, and it would corrode our moral understanding of ourselves as a society if we were to permit gross unfairness to reign simply for the sake of retaining clear rules and rational ex ante planning, particularly if those rules covertly serve the wealthy and powerful. ${ }^{91}$

The difficulty with adopting either position is that to do so suggests that we in some way have a choice between crystal and mud, whereas the history of property law tells us that we seem to be stuck with both. Even when we choose one (such as a hard-and-fast recording system), the choice seems to dissolve, and instead of really choosing, we seem to oscillate between them. Because this pattern recurs so often in so many areas, it is difficult to believe that it is due to abnormal foolishness or turpitude, or that it can be permanently overcome by a more thoughtful or more virtuous choice of one side or the other.

\section{B. Refinements on the Economic Perspective}

Some economic theory relates the crystal/mud problem to the different characteristics of the objects we consider to be "property." One theory looks to what are called "transaction costs" to explain why we sometimes have crystals and sometimes mud. Thomas Merrill has argued that where transaction costs are low-where it is easy to make a

88. Id. at 1773 (decision based on standards may be after the fact).

89. Easterbrook, supra note 79 , at 11-12.

90. Tribe, Constitutional Calculus: Equal Justice or Economic Efficiency?, 98 HaRv. L. REv. 592, 593 (1985); see also Easterbrook, Method, Result and Authority: A Reply, 98 Harv. L. Rev. 622 (1985) (responding to Tribe).

91. Tribe, supra note 90, at 595-98; cf. Easterbrook, supra note 90, at 627-29 (task of reconstituting society better left to legislatures). This argument rings curiously of the Reformation debate over whether salvation can be attained by works (i.e. one can be saved by following a prescribed course of conduct, known ex ante) or only by faith (i.e., salvation comes only through God's free act of grace). See, e.g., R.H. Tawney, Religion and the RiSe of Capitalism 86-88 (1954) (Luther's doctrine of salvation by faith contrary to established church rules of conduct and institutional structures for salvation through "works"). James Boyd White is one of the principal proponents of the idea that legal language is constitutive of culture, in the sense that it takes part in a "conversation that may define or redefine a community. See White, Judicial Criticism, 20 GA. L. Rev. 835, 846-47 (1986); see also J. B. WhrTe, WheN Words Lose Their Meaning 266-67 (1984). 
deal-we tend to have clear, hard-edged, yes-or-no rules. ${ }^{92}$ Thus, in trespass law, any invasion of my property, no matter how trivial, is an actionable wrong. Only two parties are involved; if you want to come onto my property, it is relatively easy for you to find me and to bargain with me for the right. The hard-edged rule requires you to enter into negotiations with me, and presumably if you want the right to enter more than I want to keep you out, you can offer me enough so that I will agree. The clear, crystalline rule punishes those who could easily bargain for an entitlement, but who instead bypass that opportunity and act unilaterally. ${ }^{93}$

On the other hand, the argument goes on, we find "discretionary" (or muddy) rules where the costs of transacting are high, as, for example, in the area of nuisance doctrine. ${ }^{94}$ Here the conflicts typically involve numerous parties, such as the victims of noxious odors that spread through a neighborhood. It is not easy for all affected parties to find each other, to agree on a common strategy, and to negotiate a deal whereby the sufferers pay to have the fumes stopped, or alternatively, where the fume-producing plant pays some agreed-upon price to make up for the sufferings it causes. ${ }^{95}$ Since the parties cannot easily arrive at a negotiated agreement, a court must solve the mess itself, deciding whether the costs of the fumes outweigh the benefits. Thus, where transaction costs are high, we have no nice clear deals that put a price on costs and benefits, and a court has to muddle through with conjectures. These are the scenarios in which we need judicial discretion-as well as the ambiguous, muddy doctrines that allow for judicial guesswork.

The difficulty with this explanation is that we sometimes fall back on muddy doctrines even where transaction costs are low. Wisconsin's new "nuisance" treatment of sunlight rights, for example, flies in the face of what would seem to be a relatively easy negotiation between neighbors. ${ }^{96}$ The other examples given earlier suggest the same pattern. The all but universal abandonment of the caveat emptor rule for house purchases also seems to have occurred against a backdrop of low transaction costs (one buyer, one seller), ${ }^{97}$ as does the movement to introduce equitable mushiness into the hard-edged contractual relations of mortgages and installment land contracts, ${ }^{98}$ or the repeated muddying of land record systems even when the systems are relatively easy to use. ${ }^{99}$ Thus something in the back-and-forth between crystals

92. Merrill, Trespass, Nuisance, and the Costs of Determining Property Rights, I4 J. LEgaL Stud.

$13,13-14$ (1985).

93. Id. at 25-26.

94. Id.

95. Id. at $32-34$.

96. See text accompanying notes 8-16 supra.

97. See text accompanying notes 19-30 supra.

98. See text accompanying notes $32-50$ supra.

99. See text accompanying notes 51-70 supra. 
and mud seems to elude straight transaction costs.

\section{Historians' Stories}

At least one historian, P.S. Atiyah, has noticed the shift between mud and crystal in our legal rules, and has written a long book on British contract law to illustrate the point that we have had both kinds of rules over time. ${ }^{100}$ Atiyah has argued, in effect, that our preference for mud over crystal (or vice versa) takes place in long historical cycles. Roughly speaking, he regards the eighteenth century as largely a mud era, full of ambiguity and judicial discretion, ${ }^{101}$ but he sees the period between 1770 and 1870 as an era in which crystal rules, or "principles," as he calls them, came to seem particularly important. ${ }^{102}$ His explanation (again in very gross terms) is that Parliament and the courts acted on a perceived need to discipline an unruly population during this period, and used sharply enforced legal rules to instill in the people generally the habits of foresightful, productive activity necessary to a market economy. ${ }^{103}$ The preference for crystal, under this analysis, seems to be one of education or rhetoric: you will be held to the very terms of your bargain so that, in the future, you will not be so foolish as to get yourself into such a mess, but will rather plan your affairs more carefully. ${ }^{104}$ Atiyah seems to think, with a certain regret, that we have abandoned this age of principle and are now back to a muddier ethos of "individualized justice" that he dubs "pragmatism." 105

If we look to the work of another economic historian, Albert Hirschman, we might start to think that these swings result not from external socioeconomic change or social theory, but rather result from each other. In other words, mud and crystal are not so much alternatives, but a matched pair, like +1 and -1 in a sine curve. In his book, Shifting Invalvements, ${ }^{106}$ Hirschman discusses not legal rules but rather the swing in social moods between public involvement and private selfgratification. He argues, in effect, that people desire both these ends, but that both cannot be satisfied simultaneously. Suppose one begins with private self-gratification: One's activities in behalf of one's self have certain rewards, but they also leave certain regrets, particularly over the absence of one's participation in public affairs. At some margi-

100. P.S. Atiyah, The Rise and Fall of Freedom of Contract (1979).

101. See, e.g., id. at 146-49 (discussing the highly discretionary doctrine of fair exchange). 102. Id. at 252-53; see also Atiyah, From Principles to Pragmatism: Changes in the Function of the Judicial Process and the Law (Oxford Inaugural Lecture), 65 Iowa L. Rev. 1249 (1980).

103. P.S. AtrYaH, supra note 100, at 272, 281-82, 394-96.

104. This bears a certain similarity to Tribe's idea that judicial decision-making is constitutive; both Tribe and Atiyah seem to see the mode of judicial interpretation as a matter of rhetoric, though they seem not to agree on what the content of that rhetoric should be. See also text accompanying notes 144-165 infra.

105. P.S. Atrya, supra note 102, at 1270-71. Atiyah suggests that the authority of the judiciary-and indeed the authority of the law-may be undermined by this legal ethos.

106. A. Hirschman, Shifting Involvements (1982). 
nal point where the rewards of privately-focused activity become minimal (or even negative), the actor turns to public participation. But here a similar process of satisfaction/satiation/disappointment begins. ${ }^{107}$

Might this process parallel the shift between mud and crystal in property law? Hirschman's book suggests that where we see recurring patterns, we might look for some internal-or as some theorists say, endogenous ${ }^{108}$ - factors that lead to these circular patterns. Does such an account apply to the oscillation between crystal and mud in our definitions of entitlements? We can see its application in one area at least: the recording system, where we have so often resolved uncertainty with a crystalline system, only to muddy it so thoroughly over time that we have to start all over again with a newly-minted set of clear rules.

Let us suppose that we have a system for the clarification of property titles. Might we have a tendency to overuse the system, so that in the end it becomes so hopelessly bogged down in detail that the purpose of clarity is defeated? Certainly our traditional land records have this quality. Some early cases permitted only fee interests to be recorded, but it was the very attractiveness of the system that created pressure to allow the recordation of other interests; liens, for example, or easements. ${ }^{109}$ Indeed, some claims may be in the records even though they are not legally recordable. ${ }^{110}$ Then too, many claims are recorded and just stay put over time, and sometimes even conflict with other recorded claims. The layers of these recorded but unextinguished claims can grow so thick that it hardly seems worth the time to go back and check them all. ${ }^{111}$ So, in a sense, we treat our clarifying systems-in this case the recording mechanisms-as a kind of "commons." The resulting system overload, in turn, creates a certain disgust with the lush proliferation of records. ${ }^{112}$ In fact, one of our current recording reforms would simply extinguish claims that have not been asserted during a given period. ${ }^{113}$

Thus, the very attractiveness of making clear one's claims by recording them defeats the purpose of the system, that is, to clarify all claims against a given property. One sees the same pattern in the excessively

107. Id. at $11,21,62,120$.

108. Id. at 5 .

109. See 6A R. Powelt, supra note 62, I 904[4] (gradual broadening of recordable interests); 4 AMERICAN LAW OF Property, supra note $62, \$ 17.8$, at 550.

110. See Philbrick, supra note 54, at 175-76. Philbrick argues passionately that such claims should be treated as nullities, even while noting disapprovingly that some courts treated them as giving inquiry notice, e.g., id. at 305-06.

111. See Philbrick, supra note 54, at 171-73 (conflict of old easements with later subdivided lots).

112. This is particularly noticeable in the proposals for reform. See, e.g., Lobel, supra note 64, at 501-05; Leary \& Blake, Twentieth Century Real Estate Business and Eighteenth Century Recording, 22 AM. U.L. REv. 275 (1973); Patton, supra note 53, at 227; see also Philbrick, supra note 54, at 304 (arguing that "record notice" should be limited by a test of "reasonableness").

113. For "marketable title" statutes, see note 70, supra. 
long contracts that attempt to specify all possible contingencies and that no one actually reads; however comforting it might be to "have it in writing," it really isn't worth the effort to nail down everything, and the overly precise contract may wind up being just as opaque as-and perhaps even more arbitrary than-the one that leaves adjustments to the contingencies of future relations. ${ }^{114}$

The trouble, then, is that an attractively simple legal device draws in too many users, or too complex a set of uses. And that, of course, is where the simple rule becomes a booby trap. ${ }^{115}$ It is this booby trap aspect of what seems to be clear, simple rules-the scenario of disproportionate loss by some party-that seems to drive us to muddy up crystal rules with the exceptions and the post hoc discretionary judgments. I turn now to the subject of disproportionate loss, the subject to which some courts apply the shorthand label of "forfeiture."

\section{Forfeiture as Overload: The Problem and the Players}

A strong element of moral judgment runs through the cases in which mud supersedes crystal. These cases are often rife with human failings-sloth and forgetfulness on the one hand, greed and self-dealing on the other. These vices put pressure on our efforts to elaborate clear and distinct property specifications, and make judges and others second guess the deals that call for a pound of flesh.

Perhaps we can get at this human element by thinking not about the moral qualities that are at issue, but rather about the pound of flesh. We have already seen that in the decisions about mortgages and installment land contracts, there lurks a deep antipathy to what is explicitly called the debtor's "forfeiture."116 The same antipathy to "forfei-

114. See, e.g., Leff, Unconscionability and the Code-The Emperor's New Clause, 115 U. PA. L. REv. 485, 504 (1967) (form contracts designed not to be read, consequently scrutinized clause-by-clause by some courts); see also Macneil, The Many Futures of Coniract, 47 S. CaL. L. REv. 691, 783-85, 804-05 (1974) (contrasting the formal specification of all rights in the "transactional" contracts to the more informal wait-and-see patterns in "relational" contracts). One also sees the pattern of overload in disclosure requirements: How many people really pay attention to the contents laboriously spelled out on the breakfast cereal box?

115. The overload that we place on crystal rules may have to do more with a general characteristic of linguistic change than with anything else. We treat clear or expressive terms as a "commons," and in our language pile new meanings on existing terms such that the once-simple terms change or become more complex. According to the original crystal rules for "leases," for example, a tenant would have to pay rent even if a building on the leasehold burned down. This outcome may have made sense when a "lease" was a large, income-producing agricultural property, on which the buildings were simply incidental, but it is quite bizarre when applied to a modern "lease" where the building is the central concern. Precisely because the rule does seem so bizarre, no one really expects it. See discussion in Albert M. Greenfield, Inc. v. Kolea, $475 \mathrm{~Pa} .351,380 \mathrm{~A} .2 \mathrm{~d}$ 758, 760 (1976) (law should reflect changes in purpose of lease); Crow Lumber \& Bldg. Materials v. Washington County Library Bd., 428 S.W.2d 758 (Mo. App. 1968) (discussing changes in the law). For a disaffected view of the corruption of language generally by overuse and trivialization of expressive terms, see $G$. Orwelu, Poltics and the English Language, in Collected Essays 353, 356 (1961) (discussing "dying metaphors").

116. See, e.g., Borgerding Inv. Co. v. Larson, 284 Minn. 371, 170 N.W.2d 322, 327 
ture"-a loss disproportionate to the lapse- also appears in our other examples. Thus, the non-recording (or improperly recording, or negligently recording) owner would lose the very property itself; thus, the non-inspecting (or imperfectly inspecting, or negligently inspecting) buyer would get stuck with a house that may be flooded twice a week with the neighbor's sewage.

Our law seems to find these dramatic losses abhorrent. James Gordley has written convincingly that unequal exchanges have been overwhelmingly disfavored in the western legal tradition, ${ }^{117}$ and his work suggests that rules leading to forfeitures and penalties generally are unstable in our law. Why is this so? Gordley argues that, traditionally, exchanges centering more or less around a market price counted as "equal".118 Such exchanges taken collectively restored the costs to the seller, and beyond that, Gordley argues, the law has had no reason to enforce what he calls random redistributions. ${ }^{119}$

Mark Grady has suggested something comparable to this aversion to forfeiture in another context, namely the "last clear chance" doctrine in older tort law. ${ }^{120}$ The usual rule was that one whose own negligence contributed to his injury could not recover against even a negligent injurer; if either person could have avoided the accident, the loss was left where it lay. But as Grady has pointed out, judges used the doctrine of "last clear chance" to fine-tune the respective responsibilities of the parties, to adjust those responsibilities as the time of the accident drew closer and potential foresight about it grew greater. ${ }^{121}$ In other words, the "last clear chance" doctrine could relieve an injured party from the forfeiture that would otherwise have accompanied his own careless behavior.

But the judicial double-clutching entailed in this doctrine complicated the relation between the parties, and introduced whole new layers of facts and litigative possibilities for the sake of avoiding a disproportionate loss to the injured party. Whether for efficiency reasons or not, it illustrates a way of thinking that eschews forfeitures or penalties, and that is willing to undertake an elaborate ex post analysis in order to allocate precise responsibility. ${ }^{122}$

(1969) ("forfeiture" of right of redemption not favored in Minnesota law); Barkis v. Scott, 34 Cal. 2d 116, 208 P.2d 367 (1949) (citing statute providing for relief from forfeiture); see also Campbell v. Holyland, 7 Chanc. Div. 166, 173 (1876) (explaining that a factor in favor of extending equity of redemption was danger of loss of something of special value); Maxey v. Redevelopment Authority, 94 Wis. 2d 375, 288 N.W.2d 794 (1980) (eminent domain context; lease provision to be construed so as to avoid forfeiture).

117. Gordley, Equality in Exchange, 69 CaLIF. L. Rev. 1587 (1981).

118. Id. at 1609-12.

119. Id. at 1625 . Gordley suggests this is a matter of commutative justice, a concept that has been with us since Aristotle.

120. Grady, Contributory Negligence and Railroad Sparks: An Economic Formalist Approach, 17J. LEGAL STUD. - (1988) (forthcoming).

121. Id.

122. One may note a certain similarity in Robert Rabin's analysis of the tort law's denial 
Unexpected redistribution in the tort context is one thing; but why should we find a distaste for forfeiture in people's contractual agreements about their property, as Gordley suggests we do? After all, contracting parties presumably know about the potential for forfeiture and agree to it anyway. Why complicate their relations by asking elaborate ex post questions comparable to "last clear chance"- - that is, who could have avoided the redistributive event that both apparently contemplated as a possibility? Are there reasons to make this post hoc inquiry, regardless of how firmly the parties seem to have agreed to possible forfeitures $a b$ initio?

Forfeiture might be seen as a symptom of the overloading of crystal rules. Crystalline property doctrines yield fixed consequences, and their predictability makes these doctrines attractive; but for that very reason they may be overused or overloaded in contexts that make them un predictable and counterproductive. ${ }^{123}$

Consider the way that the enforcement of a penalty affects the incentives of persons on either side of a property entitlement. If we were to enforce penalties against defaulters or violators, the persons involved undoubtedly would be especially careful about avoiding violations. But perhaps they would be too careful, and try to live up to their obligations even when circumstances changed radically, and when everyone would really be better off if someone defaulted and paid normal damages for whatever harm their default caused another. ${ }^{124}$ Penalties might also affect the behavior of the non-defaulting parties. Because they would gain much more than damages if penalties were enforced, unscrupulous dealers might expend efforts to find trading partners who would fail rather than succeed, or take measures to make them trip up, in order to take the penalty proceeds and run. ${ }^{125}$ These victims are the

of recovery for negligently inflicted economic loss: The potentially huge costs that would be levied on relatively minor wrongs seem to call out our law's "deep abhorrence to the notion of disproportionate penalties for wrongful behavior." See Rabin, Tort Recovery for Negligently Inficted Economic Loss: A Reassessment, 37 Stan. L. Rev. 1513, 1532-34. (1985).

123. Sce, e.g., Rea, Efficiency Implications of Penalties and Liquidated Damages, 13 J. LeGaL STud. 147, 160-63 (1984) (points out that damages may be unreasonable ex ante (i.e. may exceed loss ex ante), and thinks the most likely reasons may be procedural defects and certain asymmetries in information; favors ex post readjustments of such clauses (though not of those that are a reasonable guess and a reasonable reflection of risk preferences ex ante)). Some of the examples given in the present article suggest another reason for this so-called ex ante unreasonableness: the rudimentary state of legal doctrine. For example, in early mortgage law, where parties had only limited kinds of "pledges" to give for loans, the only acceptable pledge might be much more valuable than the loan. In the case of the recording system, the loss of an entire property, for failure to record, may also have reflected a dearth of remedies more precisely tailored to the fault. The interesting point about judicial rejection of the remedy in these examples is the suggestion that in some way the remedy must be tailored to the fault, or it will not be enforced. This idea is expressed in contract law in the distinction between "liquidated damages," which are acceptable, and "penalties," which are not.

124. For "efficient breach," see R. Posner, supra note 3, § 4.9, at 114-15; cf. Marschall, IVillfulness: A Crucial Factor in Choosing Remedies for Breach of Contract, 24 ARIz. L. REv. 733, 738$39,757,760$ (1982) (favors higher recovery for willful breaches because it deters breaches). 125. See note 60, supra (concerning Wisconsin land speculators' search for unrecorded 
people that petty con artists in my hometown of Chicago might call "mopes," 126 a term that undoubtedly could include the unsuspecting house purchasers who overestimate their ability to live up to the loan payments, or who never suspect that there might be rats in the basement, or who don't have a clue that they have to record their titles.

Fools on the one side and sharp dealers on the other, then, are central players in the crystal-to-mud story, because they are the characters most likely to have a leading role in the systematic overloading of crystalline rules. From this perspective, as indeed the more sophisticated economic analyses tell us, crystalline rules seem less the king of the efficiency mountain than we may normally assume. One can argue that elaborate ex post allocations of responsibilities might be efficient too, even if they make people's entitlements fuzzier ex ante. The very knowledge that one cannot gull someone else, and get away with it, makes it less likely that anyone will dissipate time and effort in trying to find the gullible. This knowledge will also reassure those of us who fear we may be made fools; we can go about our business and take part in the world of trade without cowering at home because we think we need to hire a lawyer and an accountant every time we leave the car at a commercial parking lot.

How can we fit these factors together with the scarcity story about property rights? According to that story, the driving force toward crystalline rules is the competition for resources hitherto unowned-in other words, overuse of a "commons" in a given resource. The conflicts and waste from commons overuse induce us to define boundaries around entitlements so that we can trade our entitlements instead of fighting over them. ${ }^{127}$

But the driving force of the movement to mud rules seerns to be an overuse in the "commons" of the crystal rules themselves: We are tempted to take rules that are simple and informative in one contextas, for example, "first in time, first in right" may be in a small community-and extend them to different or more complex situations, where the consequences may be unexpected and confusing. It is in these "overload" situations that crystal rules may ultimately impede trade. Not only might sharp dealers seek out situations in which trade will fail

properties); Eisenberg, The Bargain Principle and Its Limits, 95 HARv. L. REv. 741, 782-84 (1982) (discussing door-to-door sales practices as effort to find price-ignorant customers, before they undertake market searches); Rea, supra note 123, at 162 (enforcement of excess damages against mistaken promissor may induce promissee to seek out mistaken promissors); see also Dawson, Unconscionable Coercion: The German Version, 89 HARv. L. Rev. 1041,1052 (1976) (German civil code voids transactions in which one party exploits ignorance or carelessness of other with sharply disproportionate economic result); (f. Kronman, Mistake, Disclosure, Information and the Law of Contracts, $7 \mathrm{~J}$. LEGAL STUD. 1, 22-27 (1978) (disclosure should be required of those who have reason to know of other's error, and have not themselves expended resources in search).

126. Home Repair Fraud Rages, Chicago Tribune, Jan. 26, 1986, at 1, col. 3 (fraudulent home repair contractors fight over lists naming potential victims or "mopes").

127. See text accompanying notes 3-7 supra. 
(allowing them to collect a forfeiture from the mopes), but the mopes themselves may be frightened out of dealing altogether. Simple boundaries and simple remedies, it turns out, may yield radically unexpected results, and may destroy the confidence we need for trade, rather than fostering it. It is forfeiture, the prospect of dramatic or disproportionate loss, that brings this home; and forfeiture-and the detailed ways in which it might have been avoided-can only be known to us ex post.

\section{The Context of Forfeiture: Crystals and Mud as INSTITUTIONAL RESPONSES TO ESTRANGEMENT}

What can be said to generalize the context of forfeiture, where crystal rules are overloaded? Where is it in our commercial life, for example, that we find the invocation of those crystalline rules at the cost of great forfeiture to another? Stewart Macaulay's work on contracts suggests that forfeitures and penalties are called for in one context in particular: where the parties have no longterm relationship with each other. ${ }^{128}$

Now this situation is also precisely the context for the fool/scoundrel relationship. Scoundrels, of course, hope never to see their dupes again, at least after the dupes figure out that something is amiss. Contrast this ultimate form of the one-shot deal to normal business relations: Businesses that work together routinely relax the letter of their respective obligations, and readjust the terms of their relationships in the face of unexpected hardships. ${ }^{129}$ To be sure, hard-edged rules might make businessmen plan more carefully in advance; but is it worth it to do all that planning when they can write adjustment clauses into their deals? ${ }^{130}$ After all, they can trust each other, since they have to live together over the long haul. According to Macaulay, they show their hard edges, demanding forfeitures and penalties and the hard crystalline features of their entitlements only against customers whose business they are willing to forego. ${ }^{131}$

Macaulay's work, as well as that of Ian Macneil, 132 suggests that crystalline rules (and their attendant forfeitures) are only designed for people who see each other on a one-time basis, and whose temptations to dupe each other, or simply to play commercial hardball, might be strongest. ${ }^{133}$ By way of contrast, where two persons are members of

128. See Macaulay, Elegant Models, Empirical Pictures, and the Complexities of Contract, 11 LAW \&. SOC'Y REv. 507, 509 (1977).

129. See Macaulay, An Empirical View of Contract, 1985 Wis. L. Rev. 467, 467-68; Macaulay, supra note 128, at 509; see also Macneil, supra note 114, at 756-58 (relational contracts increasingly dominant), 804-05 (relational contracts expect rough spots, readjustments).

130. Macneil, supra note 114 , at 804-05.

131. Macaulay, supra note 128 , at 514 (giving the example of debt collection).

132. See Macneil, sufra note 114.

133. Macaulay, supra note 128, at 514; see also Gordon, Macaulay, Macneil and the Discovery 
the same community, religion, family, or ongoing business deal, there are inducements to cooperation and trust that are entirely independent of the enforcement of crystalline rules.

Modern game-theorist mathematicians buttress this point, telling us that if we can arrange things in such a manner that we have repeated contact with our opposite numbers, then we can enforce cooperation through the game of "tit for tat." 134 Recent historical work supports the point from another direction, telling us that prior to the eighteenth century, much European commerce was dominated by Jewish and Quaker merchants, whose family and religious connections could assure their mutual reliability. ${ }^{135}$

Recent historical literature also suggests that as modern property and contract law developed, it became possible for people to do business with each other on the basis of sheer promises even though they had none of these familial or other longterm relationships. ${ }^{136}$ The legal categories of contract acted as an artificial, officially sponsored surety for the confidence and trust that would otherwise come only through the constraints of community, religion, and family. The enforceability of clear rules enables us to deal with the world of strangers apart from these communities and to arrange our affairs with persons whom we do not know, and never expect to see again. We can do so, we think, because rules are rules are rules-we all know them, and know what to expect. Crystalline rules thus seem to perform the service of creating a context in which strangers can deal with each other in confidence.

But what is easily overlooked is that mud rules, too, attempt to recreate an underlying non-legal trading community in which confidence is possible. In those communities, the members tend to readjust for future complications, rather than drive hard bargains. Mud rules mimic a pattern of post hoc readjustments that people would make if they were in an ongoing relationship with each other. People in such relationships would hardly dupe their trading partners out of their titles, sell them defective goods, or fail to make minor readjustments on debts. If they did such things, they would lose a trading partner (or suffer denunciation in church, or become black sheep), and everyone would know it.

Now we can see why crystal and mud are a matched pair. Both are distilled from a kind of non-legal commercial context where people al-

of Solidarity and Power in Contract Law, 1985 Wis. L. Rev. 565, 569-70 (Macaulay's and Macneil's work show importance of domination in contract law).

134. R. AXelrod, The Evolution of CoOperation (1984) (game theory analysis of successful strategy for inducing and enforcing cooperation).

135. Haskell, Capitalism and the Origins of the Humanitarian Sensibility (pt. 2), 90 AM. Hist. REV. 547, 556 (1984).

136. Id. at 554-56; see also P.S. ATIYAH, supra note 100, at 139-42, 212-16 (idea of promise as having a naturally binding force developed in 18 th century thought). 
ready in some relationship arrive at more or less imperfect understandings at the outset and expect post hoc readjustments when circumstances require. Just as the parties call on courts to enforce promises and protect entitlements that would otherwise be enforced by the threat of informal sanctions, so too do they call on the courts to figure out the post hoc readjustments that would otherwise have been made by the parties themselves.

In our one-time dealings with strangers a wedge appears that splits a trading relationship into ex ante and ex post, crystals and mud. These dealings are the situations in which it seems most important to have clear definitions of obligations, but in which it is also important to have some substitute for the pattern of ongoing cooperation that would protect us against sudden and unexpected loss.

The split between crystals and mud from one-time dealings also falls along divisions in our legal institutions. We call for crystals when we are in what Mel Eisenberg has called our "rulemaking" mode, that is, when private parties make contracts with strangers or when legislatures make prospective law for an unknown future. ${ }^{137}$ We call for mud and exceptions only later, after things have gone awry, but at that point we stand before judges.

But these institutional divisions may be ineluctably different. It is obvious that "rulemakers" cannot see into the future in any very precise way when they are laying down crystal rules, and so we know that those who are in an ex ante position cannot possibly see things ex post. But it may be equally true that judges cannot think their way back into an ex ante frame of mind, in any way except metaphorically.

Borrowing a leaf from Hans-Georg Gadamer, recent scholars of historical interpretation have treated our efforts to understand the past as a kind of translation in which we cannot help but use our own experience to understand prior experience. ${ }^{138}$ This does not mean that the past perspective is incomprehensible to us, but only that our understanding of it is inevitably filtered through our subsequent experience. What we know post hoc about those fools and scoundrels necessarily transforms the way we now look at what we used to think.

Given this condition, judges, who see everything ex post, really cannot help but be influenced by their ex post perspectives. They lean ever so slightly to mud, in order to save the fools from forfeiture at the hands of scoundrels. Indeed, if judges have even an occasional preference for post hoc readjustments, to avoid forfeiture, this preference will gradually place an accretion of mud rules over people's crystalline arrangements. These considerations suggest a modification of claims

137. For Eisenberg's use of "rulemaking," see Eisenberg, Private Ordering Through Negotiaton: Dispute-Settlement and Rulemaking, 89 HARv. L. REv. 637, 664-65 (1976).

138. See Habermas, A Review of Gadamer's Truth and Method, in UNDERstanding and SoCIAL. INQUIRY 335, 336-39 (F. Dallmayr \& T. McCarthy eds. 1977); id. at 345-47 (applications in historical interpretation). 
about the efficiency of common law adjudication. We are more likely to find that judicial solutions veer towards mud rules, while it is legislatures that are more apt to join with private parties as "rulemakers" with a tilt towards crystal. ${ }^{139}$

Here, then, the circular pattern emerges: If things matter to us, we try to place clear bounds around them when we make up rules for our dealings with strangers so that we can invest in the things or trade them. The overloading of clear systems, however, may lead to forfeitures-dramatic losses that we can only see post hoc, and whose post hoc avoidance makes us (as judges) muddy the boundaries we have drawn. Then, at some point we may become so stymied by muddiness that as rulemakers we will start over with new boundaries, followed by new muddiness, and so on.

\section{Does It Matter? "Mere" Rhetoric in the Opposition of CRYSTALS AND MUd}

The crystal/mud circle occurs most strikingly in a context of dealings with strangers. But it is wise to keep in mind the limited extent of dealings of this type. Macaulay and Macneil have reminded us, as Bob Gordon notes, that the one-shot context for the enforcement of crystal rules is really quite marginal to ordinary business activity. ${ }^{140}$ Robert Ellickson's wonderful study of Shasta County suggests that property "rights" too are normally defined and readjusted by community understandings and are subject to community pressures along a number of interactive "fronts" among neighbors. ${ }^{141}$ If the context for crystal rules is marginal, then the same must be true for mud rules, insofar as mud rules attempt to inject a kind of substitute for negotiation or continuing dialogue into what would otherwise be a crystalline, open- andshut situation. No doubt there is a difference in "administrative costs" between these jurisprudential modes, ${ }^{142}$ but if most transactions take place in some kind of community or some kind of ongoing relationship, even the administrative costs should not matter very much.

Such considerations challenge the practical importance of the crys$\mathrm{tal} /$ mud dichotomy. Why then do we find so much heat in the discus-

139. For the efficiency of the common law, see Priest, The Common Law Process and the Selection of Efficient Rules, 6 J. LEGAL STud. 65 (1977); Rubin, Why is the Common Law Efficient?, 6 J. LEGAL STUD. 51 (1977). Even though crystal rules might be associated with efficiency in the sense of ease of transactions, see generally Holderness, supra note 2, post-hoc mud rules might be more efficient under some circumstances, as suggested above-especially where the costs of getting information in advance are high, or where one party effectively blocks information to another. See text accompanying notes 124-139 supra.

140. Gordon, supra note 133 , at 569,571 .

141. Ellickson, Of Coase and Cattle: Dispute Resolution Among Neighbors in Shasta County, 38 Stan. L. REv. 623, 675-76 (1986).

142. See Epstein, The Social Consequences of Common Law Rules, 95 HaRv. L. REv. 1717, 1717-18, 1742 (1982) (arguing that although common law rules generally have little social effect, different rules may have different social costs, with doctrines like negligence -my mud rules-on the high end). 
sions of these matters when relatively little in our economic life seems to hinge on them? ${ }^{143}$ If their opposition makes little difference in practice, then perhaps the answer lies in the rhetorical characteristics of crystals and mud. 144

Both crystals and mud are ways of talking about the character of our dealings with strangers, with people that we do not know and do not necessarily expect to see again. Crystal rhetoric and mud rhetoric hark back to features of our dealings with people in the very different context of an ongoing community or relationship. Thus, the rhetoric of crystals focuses on the sense of predictability and security present in longterm dealings, while the rhetoric of mud focuses on the flexibility and willingness to make adjustments that longterm dealings normally offer.

P.S. Atiyah tells us that the origins of a legal rhetoric of "principle" or crystal rules lie in the Enlightenment period, ${ }^{145}$ and this timing yields some important clues about what is at stake in the rhetorical choice between crystals and mud. Insofar as crystal rules may give us confidence and security in our dealings with strangers, it seems no coincidence that the doctrines of fixed promisekeeping and fixed property entitlements developed more or less contemporaneously with a social theory that originally envisioned a radical separateness among human beings. ${ }^{146}$ When the world is populated by strangers, one needs fixed entitlements to secure what is one's own.

A dominating strand of our inherited social theory posits a world of individuals whose dealings with each other are based on entitlement and self-interest rather than fellow-feeling ${ }^{147}$ Thus, it matters how we talk about our dealings with strangers because that is the way that we deal with everyone. I am going to suggest, however, that neither crystal rhetoric nor mud rhetoric can sustain the image of a world of strangers.

The rhetoric of crystals suggests that our safety with strangers is derived from an ability to define and bound off every entitlement with a kind of perfect language, a language that reflects in the present all future contingencies. This rhetoric suggests that, regardless of context, background, or culture, everyone understands the content of each entitlement, so that in trade, each party understands what he is giving up

143. See, e.g., text accompanying notes 71-100 supra (discussing examples of strongly held views on both sides of the debate).

144. Duncan Kennedy, in speaking about "rules" and "standards," notes these two different rhetorical styles. See Kennedy, supra note 82, at 1710-11. As mentioned earlier, the historian of contract law, P.S. Atiyah, saw the development of rules of promise-keeping - what I would call crystal-as a matter of rhetoric; "principles" were in his view a kind of public education. See note 104 supra; text accompanying notes 101-105 supra.

145. P.S. AtiYah, supra note 100 , at $345-50$.

146. See J. LockE, supra note 81, \& 21 , at 323 (men form society to avoid "State of War" among themselves); id. \$ 123, at 395 (man in state of nature is "absolute Lord" of own person and possessions, but is also "constantly exposed to the Invasion of others").

147. A. SMith, The Wealth of Nations 18 (Cannon ed. 1976) (to get what we need from others, we address their self-interest rather than their humanity); see also note 165 infra. 
and what he is gaining-or can at least "discount" any risks into a present value. ${ }^{148}$ And because of this perfect language, this perfect present understanding of the future and its contingencies, it is only fair to enforce promises and property entitlements to the limit. ${ }^{149}$

An implicit meaning of "justice" does indeed appear in the rhetoric of crystal: Adam Smith once lectured that "Justice" means "prevent[ing] the members of a society from encroaching on one anothers [sic] property, or siezing [sic] what is not their own," and he later interjected the comment that "[t]he end proposed by justice is the maintaining [sic] men in what are called their perfect rights." 150

What is wrong with this idea? The chief accusation leveled at crystal rhetoric, chiefly by scholars associated with Critical Legal Studies, is that crystalline rules are hardhearted and mean-spirited, that they glorify the attitude of self-centeredness and "me first," and that they act as a kind of coverup for the domination of the weak by the strong through the vehicle of unbridled capitalism. ${ }^{151}$ A related and in some ways more profound objection is that the notion of fixed entitlements, known or "discounted" perfectly in the present and traded around in their discounted form, is a kind of false understanding of the importance of time in human affairs. ${ }^{152}$ It is a notion that equates knowledge of human action with knowledge about the objects of nature. ${ }^{153}$ It supposes that human beings have no memories or new ideas that influence later choices, no ability to persuade each other-in short, no changes of consciousness over time that will cause them to redefine their views about "entitlements," just as they redefine other aspects of their thought. ${ }^{154}$

148. See Macneil, supra note 114 , at 801 (discussing how contract and property law allow parties to make use of future assets by translating them into present values).

149. It is not coincidental, I believe, that Richard Epstein, a well-known proponent of the crystal position, argues that the meaning of legal doctrine is stable over time. Compare Epstein, Possession as the Root of Title, 13 GA. L. REv. 1221, 1241 (1979) (first possession has had "in all past times the status of a legal rule") with Rose, Possession as Origin of Property, 52 U. CHI. L. Rev. 73, 84-85 (1985) (first possession culturally relative). Peggy Radin recently noticed that Epstein views language as stable. See Proceedings of the Conference on Takings of Property and the Constitution, 41 U. MIAMI L. Rev. 49, 73 (1986) (comment of Radin); Radin, The Consequences of Conceptualism, 41 U. MIAMT L. Rev. 239 (1986).

150. A. Smith, Lectures on JurisprudenCE 5 (R. Meek, D. Raphael \& P. Stein eds. 1978) (originally delivered 1762).

151. See Kennedy, supra note 82, at 1773; see also Mensch, Freedom of Contract as Ideology (Book Review), 33 Stan. L. Rev. 753, 766-67 (1981).

152. For a critique of the focus on the present in the crystal point of view, see Macneil, supra note 114 , at $801-03$.

153. In historical studies, this notion is reflected in the "covering law" mode of explanation. A "covering law" explanation would take the following form: Given conditions $x$ and y, results $a$ and $b$ occur. For a discussion and critical evaluation of this theory as historical explanation, see 1 P. Ricoeur, Time AND Narrative 111-20 (1984); $i d$. at 112 (the theory equates physical science and human science). Cf. Kennedy, Legal Formality, 2 J. LEGAL Stud. 351 , 381 n.50 (1973) (distinguishing the "Order of History" from the "Order of Reason"); White, Thinking About Our Language, 96 YALE L.J. 1960, 1960-66 (1987) ("conceptual" language may apply to science, but insufficiently fluid for human relations).

154. See Macneil, supra note 114, at 801-05. For an interesting discussion of the post hoc 
But if time does matter in human consciousness, then the paths we take and the things we think we are "entitled to" may be explained completely only by ex post narrative and cannot be foreseen in advance or predicted from what falsely appears to be a set of identical conditions in the past. ${ }^{155}$ To adopt the rhetoric of crystal rules, then, seems to be a way of denying the necessarily dialogic character of human interactions and acting as if we can compel human behavior by a perfect specification of unchanging rights and obligations.

But it is often forgotten that there is a much softer, more sociable and dialogic side to crystal rules and to the commerce that accompanied their development. At least some Enlightenment thinkers thought about commerce in a way that now seems novel: They hoped that commerce would enlarge sociability and would, in a sense, be a constituitive force in ever larger communities of "interest." They argued that "gentle commerce"-and presumably also the fixed entitlements that commerce seems to require-would not harden manners but rather soften them and make its practitioners more attentive to the needs of others, precisely because everyone could count on a reliable return in meeting those needs. ${ }^{156}$ Thus, commerce and fixed entitlements would create communities-at the very least, communities of interest-and the ongoing dialogue that is a part of such communities.

Lest this view be too rapidly written off as Enlightenment Panglossianism, we should note that recent historians have attributed the development of eighteenth and early nineteenth century philanthropy to the legal rhetoric of fixed entitlements and promise-keeping. It seems that confidence in firm rules did indeed instill a sense that one could deal with strangers; and when commercial traders dealt with strangers, they came to feel sympathy for the plight of those strangers, as well as confidence in their own ability to help. ${ }^{157}$ Indeed, it is hard to imagine

regrets, or at least ambiguities, that one may feel about what seem to be consensual arrangements, see West, Authority, Autonomy, and Choice: The Role of Consent in the Moral and Political Vistons of Franz Kafka and Richard Posner, 99 HaRv. L. Rev. 384 (1986); see also Posner, The Ethical Significance of Free Choice: A Reply to Professor West, 99 Harv. L. Rev. 1431 (1986); West, Submussion, Choice, and Ethics: A Rejoinder to Judge Posner, 99 HaRv. L. Rev. 1449 (1986).

155. See Taylor, Interpretation and the Sciences of Man, in UNDERSTANDING AND Social INQUIRY, supra note 138, at 101, 129; see also 1 P. RicoeUR, supra note 153, at 156-57 (distinguishing explanation-"retrospective intelligibility"-from prediction).

156. See A. Hirschman, The Passions and the Interests: Polmtical Arguments for CAPITALISM Before Its TrIUMPH 59-63 (1977); see also Hirschman, Rival Interpretations of Market Society: Civilizing, Destructive, or Feeble?, 20 J. ECON. LITERATURE 1463, 1464-66 (1982). Alexander Hamilton, however, was among those who were unconvinced that commerce softens manners. See The Federalist No. 6, at 56-57 (A. Hamilton) (C. Rossiter ed. 1961) For a recent account of the "doux commerce" debate and its impact on early thought about bankruptcy, see Weisberg, Commercial Morality, The Merchant Character, and the History of the I'oidable Preference, 39 Stan. L. Rev. 3, 18-20 (1986).

157. Haskell, supra note 135, at 555-59. Haskell's thesis has been the subject of a recent critical debate, particularly with respect to its application to the abolitionist movement. See Davis, Reflections on Abolitionism and Ideological Hegemony, 92 AM. Hist. Rev. 797 (1987); Ashworth, The Relationship Betueen Capitalism and Humanitarianism, 92 AM. Hist. Rev. 829, 852-60 (1987). 
the historical development of anything like altruism-in the sense of selfless attention to the needs of strangers ${ }^{158}$-in the absence of the far-flung commercial ties that seemed to overcome the casual savagery towards outsiders so characteristic of earlier times. ${ }^{159}$

Moreover, the language of crystal rules sometimes conveys a kind of sturdiness that, at least in our culture, suggests a very important social virtue: namely, courage. The rhetoric of firmly delineated entitlements supports that courage. One can envision almost in romantic terms the pioneer woman who, armed and ready, turns away the intruders at the threshold of her homestead cottage, ${ }^{160}$ or the tavern owners who refuse all offers to give up their little establishment and instead force the giant office building to be built around them and their happy customers. ${ }^{161}$ Even the child psychologists tell us that uncertainty about rules is not always good for us and that it does not improve our temperaments, our character, or our ability to get along with others. ${ }^{162}$

Thus, crystal rules not only depend upon shared social understandings, they at least arguably enhance sociability and facilitate ongoing social interactions. In this respect, crystal rules turn out to mirror mud rules.

It is indeed the element of ongoing social interactions that mud rules focus upon. They attempt to introduce an element of continuing dialogue among persons who acted as if they were ordering their affairs as strangers. When a court introduces ambiguity into the fixed rules that the parties initially adopted, it in effect reinstates the kind of

158. See R. Titmuss, The Gift Relationship: From Human Blood to Social Policy 88-89 (1971).

159. Haskell, supra note 135 , at 549-50 (contrasting eighteenth century individuals' growing sense of responsibility toward strangers with the casual acceptance of suffering in earlier periods). Tocqueville made a similar contrast, commenting on the brutal indifference of earlier generations of Europeans toward those perceived as outsiders; he attributed Americans' greater sympathy toward strangers to the equality of their social conditions. $2 \mathrm{~A}$. DE Tocqueville, Democracy IN AMERICA 172-77 (P. Bradley ed. 1945) (F. Bowen trans. 1862). But de Tocqueville also considered the Americans to be highly commerce-minded as well as egalitarian, and indeed the two went together. Id. at 163-67.

160. See J. Stratton, Pioneer Women: Voices from the Kansas Frontier 116-17 (1981) (pioneer woman defends Indians in her home by threatening to shoot soldiers at the door).

161. See The Holdouts: Owners Who Stay Put Play a Part in Shaping the American Skyline, Wall St. J., May 22, 1984, at 1, col. 1 (owners of Duffy's Shamrock Pub in Denver refuse to sell to developers of abutting office tower). The author has recently seen a beer commercial lauding the holdout attitude of some (presumably fictional) similarly situated tavern owners.

162. See, e.g., B. Spock, Raising Children in a Difficult Time 116-17 (1974) (firm rules give children a sense of security, and enhance the possibilities that they will be well-behaved and get along with parents). In an entirely different context, see Markovits, Pursuing One's Rights Under Socialism, 38 Stan. L. REv. 689, 743, 759-61 (1986) (contrasting politeness of entitlement-conscious West German merchants with surliness and uncooperativeness of East Germans, whose disputes are treated as family quarrels with much less regard to entitlement). For a somewhat different version of the dialogic character of rights-rhetoric, see Minow, Interpreting Rights: An Essay for Robert Cover, 96 YaLE L.J. 1860, 1866-67, 1907-08 (1987) (suggesting that rights-rhetoric carries "second meaning" calling on a larger community to enter "conversation" about previously unheard claims). 
weighing, balancing, and reconsidering that the parties might have undertaken if they had been in some longer term relationship with each other. Thus, if the mortgage can't be paid on time, the lender's expectation of prompt payment has to be weighed against the borrower's loss of the deal; if the housebuyer discovers a leaky sewage line, perhaps he should get some concession from the seller to make up for this unexpected damage. But these judicial interventions are a crude substitute for dialogue, for talking things over and adjusting entitlements, as one would be likely to do in an ongoing trading relationship, or as one would in a family or religious community.

The chief criticism leveled against mud- particularly by scholars associated with law and economics-is that, all other things being equal, mud is inefficient: Mud rules make entitlements uncertain and thus increase the costs of trading and of resolving disputes at the same time that they discourage careful planning. ${ }^{163}$ But this complaint overstates the case: At least in some instances, there is a great deal more clarity and certainty about a mud rule than a crystal one. This view is reflected in the Uniform Commercial Code, where a muddy term like "commercial reasonableness" is regarded as a standard that is more predictable to business people than such arcana as the mailbox rule of offer and acceptance. ${ }^{164}$ Perhaps we could dream up some formulation that would more clearly express our understanding than "commercial reasonableness" does, and commercial traders indeed often do so. But language is always imperfect, and much of the time it is not worth the effort to specify everything. It is easier and cheaper to rely on a set of socially understood conventions. Mud rules, then, can take on a greater clarity in a social setting among persons with some common understanding-who know, for example, that a "baker's dozen" numbers thirteen.

Just as there is a version of sociability and dialogue in crystal rules, there is a version of certainty and predictability in mud rules. These reversals occur just where crystals or mud move into a genuine social context, and it is no wonder that this is the locus of the reversal. Crystals and mud are rhetorical extractions from the practices of ongoing trading relationships where the participants are likely to enjoy both upstream security as well as downstream readjustment. In our dealings with strangers, it seems as if we can only have the one or the otherhence crystals on the one hand, for upstream security, and mud on the other, for downstream readjustment. But in fact, most of our interactions are much more sociable than the one-shot deal; we are repeat customers, we care about our reputations, and we hope that our clients

163. See, e.g., Baird \& Jackson, supra note 73, at 314; Easterbrook, supra note 79, at 10-12; Holderness, supra note 2, at 324-25.

164. See U.C.C. $\$ 2-206$ (1976) (offer is construed to invite acceptance by any reasonable manner). 
will come back. And it is at this juncture, where we establish some longterm tie, that crystals and mud dissolve into each other.

To be sure, from time to time we do deal with strangers on a oneshot basis, so that they stay strangers. Those are the points where we are faced with a choice of crystals and mud and where, over time, we seem to shift back and forth between these two jurisprudential modes. It is an illusion to think that either of these rhetorical modes are paradigms for normal living or even normal commercial dealings. Instead, they are our metaphors for the lapses of community.

But it is precisely as metaphor or rhetoric that the choice between crystal and mud matters. The lapse of community may occur only infrequently in our everyday lives, but this world of estrangement has had a robust life in our highly individualistic talk about politics and economics since the seventeenth century. ${ }^{165}$ In the context of that talk of universal individualism, the metaphoric or rhetorical character of crystals and mud has a certain independent significance. However much crystal rules may have a dialogic side like mud, ${ }^{166}$ and however much mud rules may lend the certainty of crystal, 167 as rhetoric, crystals and mud bear sharply divergent didactic messages. They suggest quite different ways that each self-contained individual should behave and converse with all those other self-contained individuals. Thus, crystal rhetoric suggests that we view friends, family, and fellow citizens from the same cool distance as those we don't know at all; ${ }^{168}$ while mud rhetoric suggests that we treat even those to whom we have no real connection with the kind of engagement that we normally reserve for friends and partners. ${ }^{169}$ And for this reason-for the sake of the different social didactics, the different modes of conversation and interaction implicit in the two rhetorical styles-we debate endlessly the respective merits of crystals and mud.

165. For a well-known recent example, see J. Rawls, A Theory of Justice 11 (1971) (principles of justice in a society are those that would be chosen by "free and rational persons concerned to further their own interests"; Rawls describes his approach as extending the contractarian theories of Locke, Rousseau, and Kant).

166. See text accompanying notes 155-162 supra.

167. See text accompanying note 164 supra.

168. See Radin, .llarkel-Inalienability, 100 HARv. L. Rev. 1849, 1877-81, 1844 (1987) (rhetoric of commodification, i.e., treating human values as commodities, distorts perceptions and alters attitudes about human relationships, particularly those of an intimate character).

169. See, e.g., Fineman, Dominant Disclosure: Professional Language and Legal Change, 101 HaRv. L. REv. - (1988) (forthcoming) (social work rhetoric of ongoing relationships may overlook needs of divorcing parties for specifications of entitlements). 